\title{
IDENTIFIKASI DAN UJI AKTIVITAS GOLONGAN SENYAWA ANTIOKSIDAN EKSTRAK KASAR BUAH PEPINO (Solanum muricatum Aiton) BERDASARKAN VARIASI PELARUT
}

\author{
Muhibbatul Husnah ${ }^{1}$; Himmatul Barroroh ${ }^{2}$; Elok Kamilah Hayati ${ }^{3}$ \\ Jurusan Kimia, Fakultas Sains dan Teknologi, Universitas Islam Negeri Maulana Malik Ibrahim \\ Malang \\ 2009
}

\begin{abstract}
ABSTRAK
Telah dilakukan penelitian dengan mengidentifikasi dan menguji aktivitas golongan senyawa antioksidan ekstrak kasar buah pepino (Solanum muricatum Aiton) berdasarkan variasi pelarut. Buah tersebut diekstrak menggunakan pelarut aquades, etanol $70 \%$, etil asetat p.a., kloroform p.a., petroleum eter p.a. dan heksana p.a. Analisis kimia pada ekstrak menunjukkan bahwa dalam ekstrak terdapat golongan senyawa asam askorbat, alkaloid dan karotenoid. Kekuatan Aktivitas antioksidan pada ekstrak diukur menggunakan metode $D P P H$ dengan parameter nilai $E C_{50}$. Nilai $E C_{50}$ Aktivitas antioksidan tertinggi dari berbagai ekstrak berturutturut (etanol $70 \%$, 22,11 $\mu \mathrm{g} / \mathrm{ml}$ ), (etil asetat, 23,81 $\mu \mathrm{g} / \mathrm{ml}$ ), (aquades, 28,31 $\mathrm{g} / \mathrm{ml}$ ), (kloroform, 30,06 $\mu \mathrm{g} / \mathrm{ml}$ ), (petroleum eter, 32,80 $\mu \mathrm{g} / \mathrm{ml}$ ) dan (heksana, 38,92 $\mu \mathrm{g} / \mathrm{ml}$ ).
\end{abstract}

Kata kunci: Aktivitas antioksidan, buah pepino, alkaloid, asam askorbat, karotenoid, DPPH

\begin{abstract}
Compound group identification and antioxidant activity test of pepino (Solanum muricatum Aiton) crude extract by solvent variation were investigated. The pepino was extracted with aquadest, ethanol $70 \%$, ethyl acetic p.a., chloroform p.a., petroleum ether p.a. and hexane p.a. Chemical analysis indicated that the antioxidant compound in pepino was ascorbic acid, alkaloid and carotenoid group. DPPH method was used to examine the antioxidant activity of the extract. The extract exhibited strong antioxidant activity in DPPH method with $E C_{50}$ value. The $E C_{50}$ value of pepino crude extract by solvent variation, from highest, were ethanol $70 \%$, ethyl acetate, aquadest, chloroform, petroleum ether and hexane of 22,11,23,81,28,3, 30,06, 32,80 and 38,92 $\mu \mathrm{g} / \mathrm{ml}$ respectively.
\end{abstract}

Keywords: Antioxidant activity, Pepino, ascorbic acid, alkaloid, carotenoid

\footnotetext{
${ }^{1}$ Mahasiswa Jurusan Kimia, Fakultas Sains dan Teknologi, UIN Maliki Malang

${ }^{2}$ Dosen di Jurusan Kimia, Fakultas Sains dan Teknologi, UIN Maliki Malang

${ }^{3}$ Dosen di Jurusan Kimia, Fakultas Sains dan Teknologi, UIN Maliki Malang
} 


\section{PENDAHULUAN}

Buah pepino (Solanum Muricatum Aiton) sekarang banyak dibudidayakan di Indonesia, karena selain sebagai makanan, juga berkhasiat sebagai obat, diantaranya untuk diabetes, stroke, tekanan darah tinggi, wasir, kanker, ginjal, sembelit, dan maag atau gangguan pencernaan lainnya (Sugiantoro, 2007). Buah pepino termasuk ke dalam suku Solanaceae. Umumnya suku ini menghasilkan alkaloid, steroid, tanpa senyawa iridoid dan biasanya tidak bertanin, tidak ada asam elagat dan terdapat antosianin (Dasuki,1991). Setiap $100 \mathrm{~g}$ pepino mengandung vitamin C $25.1 \mathrm{mg}$, protein $0.6 \mathrm{~g}$, betakaroten $26.6 \mathrm{mg}$ dan terdapat asam sitrat (Sutomo, 2008 dan IPGRI, 2004). Karena kandungan vitamin c dan betakarotennya yang cukup besar, buah pepino berpotensi dijadikan sumber antioksidan yang dapat menghambat kerja radikal bebas.

Salah satu upaya untuk mengoptimalkan pemanfaatan kandungan antioksidan buah pepino perlu dilakukan identifikasi dan uji aktifitas golongan senyawa antioksidan dalam ekstrak kasar buah tersebut dengan menvariasi pelarut pada proses ekstraksi. Pelarut dipilih berdasarkan tingkat kepolaran dengan tujuan memperoleh pelarut terbaik yaitu pelarut dapat mengekstrak golongan senyawa antioksidan yang mempunyai aktivitas tertinggi. Variasi pelarut perlu dilakukan karena senyawa aktif yang berpotensi sebagai antioksidan dalam buah pepino belum diketahui sifat kepolarannya. Ekstraksi dengan pelarut yang berbeda umumnya dapat mengekstrak jenis golongan senyawa yang berbeda.

\section{METODOLOGI}

\subsection{Alat}

Alat-alat yang digunakan dalam penelitian ini adalah seperangkat alat gelas, mortar, kertas saring, corong buchner vacum, chamber, inkubator, rotary evaporator vacum, shaker, vortex, corong pisah dan spektrofotometer UV - Vis Simadzu.

\subsection{Bahan}

Sampel yang digunakan dalam penelitian ini adalah buah pepino (Solanum muricatum Aiton) berwarna ungu dari Kebun Mulyadi Jl. Raya Junggo 106 Batu Malang.

Bahan-bahan Kimia yang digunakan adalah aquadest, etanol $70 \%$, etil asetat p.a., petroleum eter p.a., kloroform p.a., heksana p.a., etanol 95\%, $\mathrm{DPPH}, \mathrm{KMnO}_{4} 0,1 \%$, standar vitamin $\mathrm{C}, \mathrm{HCl} 37 \%, \mathrm{H}_{2} \mathrm{SO}_{4}$ pekat, asam asetat anhidrida, ammonia, pereaksi marquis, mayer dan dragendorff, dan serbuk logam Mg.

\subsection{Pembuatan Ekstrak}

Buah Pepino dibersihkan dengan air, dikupas, dipotong kecil-kecil, dibuang isinya, ditimbang 600 gram kemudian diblender (tanpa penambahan pelarut). buah pepino yang telah dihaluskan, ditimbang sebanyak 100 gr dan dimaserasi dengan $200 \mathrm{ml}$ aquades menggunakan shaker berkekuatan $120 \mathrm{rpm}$ selama 24 jam (Bernasconi, 1995 dan Yustina, 2008). Setelah itu disaring dengan corong buchner vacum. Apabila filtrat yang diperoleh terdapat dua lapisan maka dipisahkan berdasarkan berat jenisnya. Filtrat yang diinginkan dipekatkan dengan rotary evaporator vacum sehingga diperoleh ekstrak kasar.

Ekstrak kasar yang diperoleh selanjutnya diidentifikasi golongan senyawa antioksidannya dan aktivitas antioksidannya. Perlakuan tersebut juga berlaku pada tiap-tiap pelarut yaitu etanol $70 \%$, etil asetat p.a., petroleum eter p.a., kloroform p.a., heksana p.a.

\subsection{Identifikasi Golongan Senyawa Antioksidan Secara Kualitatif}

\subsubsection{Identifikasi Karotenoid}

Ekstrak kasar buah pepino dengan pelarut aquades dan etanol $70 \%$, masingmasing diambil $15 \mathrm{mg}$ dan dimasukkan dalam tabung reaksi, ditambahkan $5 \mathrm{ml}$ etanol $95 \%$ dan divortex selama 1 menit. Ditambahkan 10 $\mathrm{ml}$ petroleum eter, kemudian tabung reaksi ditutup dan divortex selama 10 menit. Lapisan aquades dan etanol $70 \%$ dipisahkan dan dicuci dengan petroleum eter dalam corong pisah. Masing masing lapisan diambil $1 \mathrm{ml}$ lapisan ditambahkan etanol 95

$\%$ sebanyak $4 \mathrm{ml}$ dan divortex, kemudian diukur panjang gelombangnya dengan 
spektrofotometer dengan $\lambda$ gelombang 500 $600 \mathrm{~nm}$.

Ekstrak petroleum eter diambil $15 \mathrm{mg}$ dan dimasukkan dalam tabung reaksi, ditambahkan $5 \mathrm{ml}$ etanol $95 \%$ dan divortex selama 1 menit. Ditambahkan $10 \mathrm{ml}$ petroleum eter, kemudian tabung reaksi ditutup dan divortex selama 10 menit. Endapan dipisahkan dengan larutan yang mengandung karotenoid. Larutan yang mengandung karotenoid dicuci dengan aquades dalam corong pisah. Diambil $1 \mathrm{ml}$ lapisan dan ditambahkan petroleum eter sebanyak $4 \mathrm{ml}$ dan divortex, kemudian diukur panjang gelombangnya dengan spektrofotometer dengan $\lambda$ gelombang 500$600 \mathrm{~nm}$. Perlakuan tersebut dilakukan pada ekstrak pelarut etil asetat, kloroform, dan heksana dengan mengganti petroleum eter dengan pelarut ekstraknya, kecuali ekstrak etil asetat pada waktu pengukuran panjang gelombang maksimumnya menggunakan pelarut etanol 95\% (Murkanindyo, 2006).

\subsubsection{Identifikasi Steroid}

Masing-masing ekstrak kasar diambil 5 mg dilarutkan dalam 2-3 ml kloroform, lalu ditambahkan 10 tetes asam asetat anhidrida dan 2-3 tetes $\mathrm{H}_{2} \mathrm{SO}_{4}$ pekat. Pembentukan warna biru sampai hijau menunjukkan adanya steroid (Auterhoff, 1987).

\subsubsection{Identifikasi Flavonoid}

Masing-masing ekstrak kasar $5 \mathrm{mg}$ ditambahkan 1-2 ml air panas dan sedikit serbuk Mg. Kemudian ditambahkan $\mathrm{HCl} 37 \%$ dan etanol 95\% masing-masing 4-5 tetes lalu dikocok. Jika terbentuk warna merah, kuning atau jingga pada larutan tersebut, maka ekstrak kasar positif mengandung flavonoid (Febriany, 2004).

\subsubsection{Identifikasi Alkaloid}

Masing-masing $5 \mathrm{mg}$ ekstrak kasar ditambahkan $2 \mathrm{ml}$ kloroform dan $2 \mathrm{ml}$ amonia lalu disaring. Filtrat ditambahkan 3-5 tetes $\mathrm{H}-$ ${ }_{2} \mathrm{SO}_{4}$ pekat untuk menetralkan lalu dikocok hingga terbentuk dua lapisan. Lapisan asam yang tak berwarna diuji dengan menambahkan reagen marquis, mayer dan dragendorff masing-masing 4-5 tetes. Jika pengujian dengan reagen marquis, mayer dan dragendorff menghasilkan warna berturut-turut kuning sampai merah lembayung, putih keruh dan jingga maka ekstrak kasar tersebut mengandung alkaloid (Febriany, 2004 dan Harborne, 1987).

\subsubsection{Identifikasi Asam Askorbat}

Masing-masing $5 \mathrm{mg}$ ekstrak dan Standar vitamin $\mathrm{C}$ dilarutkan dalam aquadest 5 $\mathrm{ml}$, kemudian ditambahkan $10 \mathrm{ml}$ larutan $\mathrm{KMnO}_{4} 0,1 \%$. Jika terbentuk warna cokelat maka menunjukkan adanya asam askorbat (Auterhoff, 1987).

\subsection{Uji Aktivitas Antioksidan Menggunakan Metode DPPH}

\subsubsection{Absorbansi kontrol}

Larutan DPPH dengan konsentrasi 0,2 $\mu \mathrm{M}$ dalam etanol $95 \% \mathrm{v} / \mathrm{v}$ diambil $1 \mathrm{ml}$ kemudian diinkubasi pada suhu $37^{\circ} \mathrm{C}$ selama 30 menit, setelah itu diukur absorbansinya pada panjang gelombang $517 \mathrm{~nm}$.

\subsubsection{Sampel (ekstrak kasar)}

Masing-masing ekstrak kasar dilarutkan dalam dengan konsentrasi $1,5,10,15,25,50$, 100, 200, 400, 800, dan 1000 ppm. Kemudian tiap-tiap konsentrasi dari tiap-tiap ekstrak kasar diambil 0,75 ml dan ditambahkan larutan DPPH $0,2 \mu \mathrm{M}$ dalam etanol $95 \% \quad \mathrm{v} / \mathrm{v}$ sebanyak $0,25 \mathrm{ml}$. Setelah itu diinkubasi pada suhu $37^{\circ} \mathrm{C}$ selama 30 menit, kemudian dimasukkan kuvet untuk diukur absorbansinya pada panjang gelombang $517 \mathrm{~nm}$. Tiap sampel dilakukan pengulangan tiga kali (triplo). Data absorbansi yang diperoleh dari tiap konsentrasi masing-masing ekstrak dihitung nilai \% aktivitas antioksidannya. Nilai tersebut diperoleh dengan rumus (Molyneux, 2003):

$\%_{\text {Aktivitas antioksidan }}=\left(\frac{\mathrm{Ak}-\mathrm{As}}{\mathrm{Ak}}\right) \times 100 \%$

Keterangan: $\mathrm{Ak}=$ Absorbansi kontrol As $=$ Absorbansi sampel

\subsubsection{Pembanding BHT}

Larutan BHT diberi perlakuan sama dengan perlakuan sampel hingga diperoleh \% aktivitas antioksidan.Selanjutnya masingmasing ekstrak dihitung nilai $\mathrm{EC}_{50}$ nya dengan 
menggunakan menggunakan program GraphPad prism5 software, Regression for analyzing dose-response data.

\section{HASIL DAN PEMBAHASAN}

Hasil identifikasi golongan senyawa antioksidan pada ekstrak kasar buah pepino menunjukkan bahwa dalam ekstrak tersebut mengandung golongan senyawa asam askorbat, alkaloid dan karotenoid. Adapun hasil identifikasi golongan senyawa antioksidan yang terdapat dalam ekstrak tersebut untuk lebih jelasnya disajikan pada Tabel 1. Penelitian ini menggunakan metode DPPH (1,1-difenil-2-pikrilhidrazil) sebagai metode uji antioksidan. Metode DPPH dipilih karena sederhana, mudah, cepat dan peka serta hanya memerlukan sedikit sampel. Senyawa antioksidan akan bereaksi dengan radikal DPPH melalui mekanisme donasi atom hidrogen menjadi DPPH-H yang diamagnetik karena adanya pasangan elektron. Keadaan yang diamagnetik pada DPPH-H ini tidak bersifat radikal bebas lagi. Reaksi tersebut menyebabkan terjadinya perubahan warna DPPH dari ungu ke kuning yang diukur pada panjang gelombang $517 \mathrm{~nm}$ (Prakash, 2001).

Hasil uji aktivitas antioksidan menggunakan metode DPPH berdasarkan persen aktivitasnya (Tabel 2) menunjukkan bahwa aktivitas antioksidan pada semua ekstrak kasar efektif pada konsentrasi 100 ppm. Ekstrak aquades, etanol $70 \%$, etil asetat dan kloroform pada konsentrasi 400 ppm masih efektif. Akan tetapi aktivitasnya konstan dimana terjadi peningkatan aktivitas antioksidan yang tidak begitu berarti. Pada konsentrasi 800 dan 1000 ppm , aktivitas antioksidan mengalami penurunan. Aktivitas antioksidan ekstrak petroleum eter dan heksana masih efektif pada konsentrasi 800 ppm. Pada konsentrasi 1000 ppm, aktivitas keduanya telah menunjukkan sedikit penurunan. Aktivitas penangkapan radikal bebas atau antioksidan tertinggi rata-rata didapatkan pada konsentrasi 400 ppm. Hal ini berarti bahwa penangkapan radikal bebas masih efektif sampai konsentrasi 400 ppm, dan belum menjadi prooksidan.

Tabel 1. Hasil identifikasi golongan senyawa antioksidan ekstrak kasar buah pepino

\begin{tabular}{|c|c|c|c|c|c|c|}
\hline \multirow{2}{*}{$\begin{array}{c}\text { Golongan } \\
\text { senyawa } \\
\text { antioksidan }\end{array}$} & \multicolumn{6}{|c|}{ Pelarut } \\
\hline & Aquades & $\begin{array}{l}\text { Etanol } \\
70 \%\end{array}$ & $\begin{array}{c}\text { Etil asetat } \\
\text { p.a. }\end{array}$ & $\begin{array}{c}\text { Kloroform } \\
\text { p.a. }\end{array}$ & $\begin{array}{c}\text { Petroleum } \\
\text { eter p.a. }\end{array}$ & $\begin{array}{c}\text { Heksana } \\
\text { p.a. }\end{array}$ \\
\hline Karotenoid & - & - & - & + & + & + \\
\hline Steroid & - & - & - & - & - & - \\
\hline \multicolumn{7}{|l|}{ Alkaloid: } \\
\hline -Marquis & - & ++ & + & + & - & - \\
\hline -Mayer & ++ & ++ & ++ & + & - & - \\
\hline -Dragendorff & + & + & + & + & - & - \\
\hline Flavonoid & - & - & - & - & - & - \\
\hline $\begin{array}{c}\text { Asam } \\
\text { askorbat }\end{array}$ & ++ & ++ & + & - & - & - \\
\hline
\end{tabular}

Keterangan: $++=$ terkandung senyawa lebih banyak, $+=$ terkandung senyawa, $-=$ tidak terkandung senyawa 


\begin{tabular}{cccccccc}
\hline $\begin{array}{c}\text { Konsentrasi } \\
(\mathbf{p p m})\end{array}$ & \multicolumn{7}{c}{ Aktivitas antioksidan (\%) } \\
\cline { 2 - 8 } & $\begin{array}{c}\text { Ekstra } \\
\mathbf{k}\end{array}$ & $\begin{array}{c}\text { Ekstra } \\
\mathbf{k}\end{array}$ & $\begin{array}{c}\text { Ekstra } \\
\text { k etil }\end{array}$ & $\begin{array}{c}\text { Ekstrak } \\
\text { Klorofor }\end{array}$ & $\begin{array}{c}\text { Ekstrak } \\
\text { Petroleu }\end{array}$ & $\begin{array}{c}\text { Ekstrak } \\
\text { Heksan }\end{array}$ & $\begin{array}{c}\text { Pembandin } \\
\text { g BHT }\end{array}$ \\
\hline $\mathbf{1}$ & 6,42 & 11,47 & 8,15 & 4,28 & 3,56 & 3,7 & 17,86 \\
$\mathbf{5}$ & 12,64 & 19,68 & 16,38 & 9,49 & 6,55 & 11,91 & 34,74 \\
$\mathbf{1 0}$ & 18,52 & 27,08 & 33,82 & 15,85 & 13,79 & 19,95 & 43,87 \\
$\mathbf{1 5}$ & 40,09 & 40,43 & 41,61 & 41,48 & 23,75 & 28,58 & 51,81 \\
$\mathbf{2 5}$ & 53,81 & 53,56 & 54,56 & 54,50 & 51,85 & 43,54 & 58,49 \\
$\mathbf{5 0}$ & 62,16 & 68,93 & 62,20 & 65,22 & 66,97 & 61,38 & 77,15 \\
$\mathbf{1 0 0}$ & 80,29 & 87,03 & 81,61 & 76,67 & 79,68 & 75,07 & 89,53 \\
$\mathbf{2 0 0}$ & 81,81 & 88,23 & 82,05 & 78,51 & 81,69 & 75,84 & 91,97 \\
$\mathbf{4 0 0}$ & 85,64 & 88,95 & 85,55 & 79,70 & 82,53 & 76,96 & 92,05 \\
$\mathbf{8 0 0}$ & 82,68 & 87,66 & 84,55 & 77,92 & 82,97 & 80,20 & 86,93 \\
$\mathbf{1 0 0 0}$ & 77,76 & 86,97 & 84,06 & 76,86 & 79,23 & 77,85 & 85,59 \\
\hline
\end{tabular}

Semakin besar konsentrasi ekstrak yang ditambahkan, aktivitas antioksidannya akan meningkat. Akan tetapi, bila penambahan antioksidan melebihi batas, maka aktivitas antioksidan akan berubah menjadi aktivitas prooksidan karena dapat mempengaruhi laju oksidasi (Gordon, 1990 dalam Trilaksani, 2003). Hal itu dibuktikan hampir semua konsentrasi masing-masing ekstrak 800-1000 ppm terjadi penurunan aktivitas.

Persen aktivitas antioksidan yang diperoleh selanjutnya dianalisis menggunakan persamaan regresi non linear dan dihitung menggunakan "GraphPad prism5 software, Regression for analyzing dose-response data" untuk memperoleh nilai $\mathrm{EC}_{50}$. Semakin kecil nilai $\mathrm{EC}_{50}$ suatu senyawa uji maka senyawa tersebut semakin aktif sebagai antioksidan (Molyneux, 2003). Konsentrasi yang digunakan untuk mendapatkan nilai tersebut dari tiap ekstrak hanya dari 1 sampai 400 ppm. Hal itu dikarenakan rata-rata tiap ekstrak pada konsentrasi 800 dan 1000 ppm sudah tidak efektif lagi sebagai antioksidan.

Nilai $\mathrm{EC}_{50}$ pada Tabel 3 menunjukkan bahwa ekstrak etanol $70 \%$ mempunyai aktivitas antioksidan lebih tinggi dibandingkan dengan ekstrak-ekstrak yang lain. Hal itu dimungkinkan karena adanya kandungan senyawa aktif dari beberapa golongan senyawa antioksidan. Hasil identifikasi pada Tabel 1 membuktikan bahwa ekstrak etanol $70 \%$ mempunyai golongan senyawa antioksidan asam askorbat dan alkaloid dimana golongan tersebut dapat berfungsi sebagai antioksidan dengan menyumbangkan atom hidrogennya pada radikal DPPH sehingga radikal DPPH menjadi DPPH-H. Begitu juga dengan ekstrakekstrak yang lain. Semua ekstrak memiliki aktivitas antioksidan baik dari pelarut polar maupun non polar. Perbedaan aktivitas antar ekstrak tersebut kemungkinan disebabkan adanya perbedaan beberapa kandungan senyawa aktif yang terdapat dalam ekstrak dan jumlahnya, sehingga aktivitas antioksidannya dalam menangkap radikal bebas DPPH hasilnya juga berbeda. Apabila dibandingkan dengan aktivitas antioksidan BHT yang mempunyai nilai $\mathrm{EC}_{50}$ sebesar $12,23 \mu \mathrm{g} / \mathrm{ml}$, aktivitas antioksidan ekstrak kasar buah pepino masih lebih rendah. 
Tabel 3. Aktivitas antioksidan tiap ekstrak dan pembanding $\mathrm{BHT}$ berdasarkan nilai $\mathrm{EC}_{50}$

\begin{tabular}{cc}
\hline Ekstrak & Aktivitas antioksidan $\left(\mathbf{E C}_{\mathbf{5 0}} \boldsymbol{\mu} \mathbf{g} / \mathbf{m l}\right)$ \\
\hline Aquades & 28,31 \\
Etanol $70 \%$ & 22,11 \\
Etil asetat p.a. & 23,81 \\
Kloroform p.a. & 30,06 \\
Petroleum eter p.a. & 32,80 \\
Heksana p.a. & 38,92 \\
\hline
\end{tabular}

\section{KESIMPULAN}

Dari hasil penelitian ini dapat disimpulkan bahwa ekstrak kasar buah pepino mempunyai aktivitas antioksidan, dan golongan senyawa yang berkhasiat sebagai antioksidan yaitu asam askorbat, alkaloid dan karotenoid.

\section{SARAN}

Diperlukan penelitian lebih lanjut dengan memfraksinasi ekstrak kasar buah pepino agar dapat diketahui senyawa yang berpotensi sebagai antioksidan tersebut.

\section{DAFTAR PUSTAKA}

Autorhoff, H., dan Kovar, K.A, 1987, Identifikasi Obat, Bandung: ITB

Bernasconi, G., "dkk", 1995, Teknologi Kimia 2, Penerjemah: Handojo L., Jakarta: PT Prandya Paramitha

Dasuki, U.A., 1991, Sistematik Tumbuhan Tinggi, Bandung: ITB

Febriany, S., 2004, Pengaruh Beberapa Ekstrak Tunggal Bangle dan
Gabungannya yang Berpotensi Meningkatkan Aktivitas Enzim Lipase Secara In Vitro, Bogor: Fakultas MIPA IPB

Gonzalez, M.,"et al", 2000, Colour and Composition of Improved Pepino Cultivars at Three Ripening Stages, Gartenbauwissenschaff, 65 (2),s,8387,2000 , ISSN 0016-478X, Verlag Eugen Ulmer GmbH and Co., Stutgart

Harborne, J,B, 1987, Metode Fitokimia Penuntun Cara Modern Menganalisis Tumbuhan, Bandung: ITB

IPGRI, 2004, Descriptors of Pepino, Solanum muricatum, International Plant Genetic Resources Institute, ISBN 92-9043616-6, http://www.ipgri.cgiar.org. diakses 19 januari 2008

Molyneux, P., 2003, The Use of The Stable Free Radical Diphenylpicrylhydrazyl (DPPH), for Estimating Antioxidant Activity, Songklanakarin J. Sci. Technol., 2004, 26(2) : 211-219

Murkanindyo, B. D, 2006, Perencanaan Industri Tepung Wortel (Daucus carot L.), Malang: FTP UNIBRAW

Purnama, D.A., Sarno, 2005, Pepino Buah Mewah Berkhasiat Obat, Yogyakarta: Penerbit Kanisius. 